IRA-International Journal of Management \& Social Sciences

ISSN 2455-2267; Vol.04, Issue 03 (2016)

Pg. no. 562-567

Institute of Research Advances

http://research-advances.org/index.php/RAJMSS

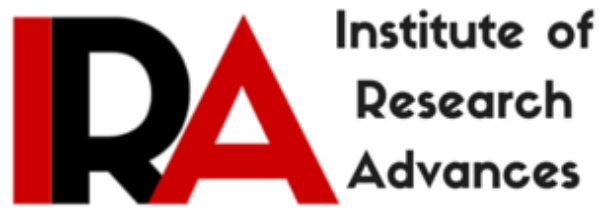

\title{
Globalization and Muslims: The Concerns \& Contradictions
}

\author{
Dr. Mohd. Habib \\ Department of Religious Studies, \\ Punjabi University, Patiala, India.
}

Type of Review: Peer Reviewed.

DOI: http://dx.doi.org/10.21013/jmss.v4.n3.p6

\section{How to cite this paper:}

Habib, M. (2016). Globalization and Muslims: The Concerns \& Contradictions. IRA-International Journal of Management \& Social Sciences (ISSN 2455-2267), 4(3), 562-567. doi:http://dx.doi.org/10.21013/jmss.v4.n3.p6

(C) Institute of Research Advances

\section{(cc) EY-NC}

This work is licensed under a Creative Commons Attribution-Non Commercial 4.0 International License subject to proper citation to the publication source of the work.

Disclaimer: The scholarly papers as reviewed and published by the Institute of Research Advances (IRA) are the views and opinions of their respective authors and are not the views or opinions of the IRA. The IRA disclaims of any harm or loss caused due to the published content to any party. 
Globalization has been defined in many different ways as the subject has been dealt by many philosophers, social scientists and policymakers with various approaches. Here for the convenience to elaborate the subject, we use the definition of Roland Robertson a known scholar of the subject who applies the term to 'a consciousness of the growing connectivity and integration not only between countries and region of the world but also between all manner of economic, political and cultural spheres and processes, 1

The earliest origin of the process of globalization is traced with the beginning of modernity after the Renaissance in the West. During eighteenth and early nineteenth centuries the modernity emerged in European civilization with secular humanism and gradual decline of religion and morality. It was the time when Christianity removed from the public sphere but Christian morality particularly protestant remain still alive. That morality was intertwined and collaborated with the system of capitalism in economical and industrial terms, as the modernity and globalization is the direct out come of the industrial capitalism. The values of this system spread worldwide by the imperialism of Europe and later on of America.

Here, it is not possible to discuss the whole process of globalization and its ramifications, as the goal of this paper is just to analyze in brief the concerns of the Muslims in India and the world as a reflection of the process of modernity and globalization. It will explain why the Muslims are not ready to emulate the West as such. In this paper I am largely benefited by the ideas of Ejaz Akram, which he had expressed on the subject 'The Muslim World and Globalization' 2

Some people assume that "Globalization" has always existed as per the above mentioned definition because the movement of people, ideas and goods has been a universal process. But the current form of the globalization is a direct out come of the western modernity. Therefore, it is particular not universal. Victor Segesvary argues that it is a "drive towards conquering other cultural worlds by the worldview, forms of life and styles of reasoning developed with in Western Civilization." 3 He further says that it is not also a 'universal' type of contact between Islam and the west, referring that how the European mind first time opened toward other civilizations as a consequence of the first Latin translation of the holy Qur'an in 1543. However, the present form of globalization is particular because its foundational principles lie embedded in historical events restricted to European history alone. ${ }^{4}$

For much of the non-European world, globalization started with the European colonialism. Many Muslim countries were also directly or indirectly colonized. Even after formal independence, they are still entangled in a net of financial and diplomatic dependency. That is the reason why many Muslims take the current form of globalization as hegemony of the West and not willingly open to accept it but suspicious and consider it another form of colonialism. It created a fear of invasion of American culture to the Muslim culture and their religious identity.

There are some other political, economical and socio-religious reasons also due to which the Muslim response towards modernity and Globalization is ambivalent and suspicious. Modernity fragmented the political unity of the Muslim Ummah-the Worldwide Muslim community. The various nation-states of the Muslims had not yet been able to establish the Western type of democracy. It is because the Muslim masses consider the Shariat Law sacred to govern the whole affairs of life and not limited to the religion as a matter of private life as modernity required. The modern system is based on human ideologies where as the Muslim thought and social system is based on transcendent realities. They consider the Supreme Being the only law-giver to humanity whose rules should prevail on Earth as a Creator. Men are his representative and supreme creation on Earth. That is why the modern secular and materialistic view of the world is radically different from the Muslim world view. To them the system of the modern nation-state is threat to peace. It creates the boundary problems and race of arms, individuality, conflict in human races and irrational glorification of sectarian cultures. 
There is a permanent problem of democracy in Muslim states due to the contradictory world view of the West and the Muslims, regarding the concept of democracy itself. If the Muslims try to establish their own form of democracy called as Islamic democracy, the western policy makers and the mighty states jeopardize it to meet their own vested interests. Algeria and Palestine are glaring examples of it. This phenomenon creates anti-western resentment in the minds of many Muslims.

The same is the problem of the modern economies. Muslims have their own Islamic rules and regulations of market and finance, which are contradictory to the modern profit, and interest based competitive market and economics. It is not possible here to give all the concerning details.

Study of the writings of the Muslim religious scholars reveals that they are highly critical to the achievements of Modernity. They consider the claims of Modernity-freedom, equality and fraternity-just mere dreams, which did not come true. To them the claims of sexual equality was a gimmick, which makes woman more subjugated than before. She has been degraded to the level of consumer object in the market. Muslims as per Islamic ideology don't accept identical equality of sexes but idealical equality. To them men and women are not equal but complement of each other. That is the reason why they divide the rights and duties with some necessary variations. Besides, the unequal economical opportunities and a high gap between the rich and the poor; the plutocracy in the name of democracy, makes the modernity in the eyes of the Muslims a valueless immoral and anarchic system.

Another socio-cultural aspect of globalization is the spread of secularism to the Muslim world. Secularism requires the social conditions in which religion lost its central significance to the society. Moreover, the nature of globalization is all-inclusive which is diminishing the religious and social identities. The fear of all-inclusive nature of globalization and spread of secularism, making the Muslim societies more exclusive in the matter of faith. The effect of it may be seen on many Muslim societies getting more religious, despite the fact that the pressure of globalization transforming them into mass societies. The all-inclusive pressure of globalization is producing more reactionary movements among the Muslim masses and paving the way to the extremism rather than presenting the spiritual peace message of Islam. $^{5}$

As per the doctrine of Islam, the idea of God is inbuilt into human nature. If it will not be allowed to express in natural way, it will manifest itself in other ways. That is the reason why the total denial of religion even in secular societies and government system takes the form of fanaticism. Examples may be given of Rashtriya Swayamsevak Sangh (RSS) and Sangh parivar in secular India, having religious referent but violent behavior to non-Hindus. Likewise, Israeli Zionism has a religious referent though the state has a secular ideology. ${ }^{6}$

It is a fact that the secularism has its different variables. However, the process of globalization of the modern value system produced exogenous pressure for secularism in the Muslim world. But Islamic value system and governing laws does not classify life into two unconnected halves, one is sacred and the other profane. The Islamic sacred law covers all walks of life and makes life coherent with transcendental reality. It is the main reason why the forceful imposition of secularism in the Muslim world is producing violent reactions against the modernism and globalization. ${ }^{7}$

Evolutionism and the myth of progress is also a cause of the Muslims reaction against the globalization. The theory of evolution is an out come of biology and natural sciences. It is taught at the schools not as a theory but as a fact. It has a gradual impact on social sciences also. It is closely linked to the idea of progress, which radically changed the worldview, which is very negation to the Islamic worldview. This theory has produced a social view of 'might is right' according to which only the stronger would survive. This worldview justifies the right to rule of superior races over the lower and backward races. It also justifies the capitalist free market system, in which there is no sympathy and 
compassion, for the weak. On the contrary Islam not justifies these kinds of socio-economic values. It also not approves another extremist socio-economic point of view of the communists and the socialists who insists on a utopian equality of opportunities and conditions but stands to the middle path and balance of both. Globalization of such ideas has created a general fear in Muslim societies of being culturally invaded by the forces of modernism. ${ }^{8}$

In spite of the all above reservations and deterrents, the Muslim societies hugely impacted in various ways by the process of modernism and globalization. The activism of modernity stirred the smooth sea of the Muslim civilization. W.C. Smith opines in the context of Indian Muslims living in the mid of twentieth century, 'In the nineteenth century, that people (Muslims) was backward and somnolent, with traditions of past grandeur, to-day parts of it, at least, are much awake... ${ }^{9}$ He further says,

The young Indian Muslims of today, living new lives, think different thoughts from those of their fathers and grandfather's years before them. And the latter's lives and thoughts were different also from those of their grand father's fifty years still earlier. ${ }^{10}$

The change in the Muslim thoughts and approaches came slowly and steadily since they first encountered with modernity and globalization in the nineteenth century. The wave of change in the Muslim attitude first began by the reform movements favouring the contemporary western culture in various Muslim countries. W.C. Smith as earlier mentioned took the notice of this change in India. He said that it was a first time change in Muslim attitude due to a this-worldly dynamic approach, which was new at that time. The champion of this movement was Sir Sayyid Ahmad Khan who had established liberal Aligarh school in the latter part of the century. Islamic literature of this period stresses on the similarities between Christianity and Islam. ${ }^{11}$

The next wave of Indian Islamic modernism starts when by the impact of British rule, the Indian industrialism takes a visual form and an Indian middle class comes as a rival to the British bourgeoisie. In this period Islam was elaborated as a compatible faith to the modernity and as a very source of the Western liberalism. Moreover, Christianity was interpreted as a rival faith and a religion inferior to Islam. The grandeur of Islamic Medieval culture was depicted with enthusiasm and as a glorification of the Muslim achievements. One stimulus for that was activism of the Christian missionaries in India. In other words, Islamic modernization of this time was in reaction of the criticism of the missionaries. W. C. Smith identified it as a movement in favour of Islamic culture of the past. Amir Ali is recorded as the noted figure in the Movement. Uthmaniyah University, Hyderabad was also established in this background. ${ }^{12}$

When the above Movements had became ineffective, the Islamic Modernism in India entered in a new phase. It was a progressive attempt in the beginning but gradually became a reactionary in the later period. W.C. Smith opines that it was a movement in favour of a new Islamic culture of the future. It had appealed to those Muslims who look to the future rather than to either the present or the past. It shows the growing frustration not only of Indian Muslim middle class but also of all Indian bourgeoisies who were finding lesser opportunities to grow under the imperialistic capitalism. They had been looking therefore to abolishing the present system and building a new one suitable to their desire. This movement was repudiating not only the West but also Westernism itself. ${ }^{13}$ Pioneers of the movement unlike their predecessors did not glorified medieval Muslim culture and Abbasi Khilafat as that was too an imperialistic to them. Rather they had stressed the very early period of Islam from Prophet Muhammad to Khilafat-e-Rashida- the last thirty years after the Prophets' death.

The outstanding figure in both phases-progressive and reactionary - of this movement was Sir Muhammad Iqbal who summoned the sleeping Muslims to wakeup. University, Jamia Millia Islamia, Delhi also established in the progressive phase of this movement. In its reactionary phase certain 
reactionary changes also occurred in the ideology of some of the pioneers of Aligarh Muslim University, Aligarh. Iqbal's poetry and other writings of that period are the best reflection of the movement. In fact, This progressive and futuristic visionary movement soon affected by the fast changing political situations of Indian nationality and demand for freedom. The compelling circumstances changed its progressive course to reactionary one. Later on, it opposed the Hindu Nationalism and intermixed with Muslim nationalistic movement and demand for Pakistan, which finally reflected in communal fanaticism - the very negation of its origin. ${ }^{14}$

In this process of Indian Islamic Modernism many theological movements and congregations also came into existence, such as the Ahmadiyah Movement, Jamaat Islami, Tablighi Jamaat, Jamiat Ulema-eHind, Jamiat Ahl-e-Hadith etc.

Just as India, other Muslim states were also facing the same kind of social and cultural change. The History of Turkey, Iran, Egypt and Afghanistan etc reflects the similar process of Islamic modernism. Hopefully we can say that in the contemporary period of Globalization a synthesis will take place in Islamic modern reformatory thoughts and the Western liberal ideas. We are observing a positive change in new Islamic literature and new interpretations of the Holy Qur'an by the Muslims and the NonMuslims alike. Some efforts also going on to interfaith understanding and to develop a new Islamic fiqhjurisprudence suited to the New Age requirements. Ashgar Ali Engineer opines that Muslims particularly who are living in European countries and their respective cultures will certainly comes to terms with role of basic freedoms in Western societies. They will have to develop a new fiqh fit for democratic culture. ${ }^{15}$

Islamic radicalism and Western imperialism both are menace to humanity. The efforts should be made to check the both. The champions of Globalization also should come forward to make some necessary corrections so as to make the globalization fruitful to all the sections of human society.

\section{Reference}

1. James A. Beckford, Social Theory and Religion, Cambridge university Press, Cambridge, 2003, p.108

2. Ejaz Akram, The Muslim World and Globalization: Modernity and the roots of conflict: Islam, Fundamentalism and the Betrayal of Tradition, edited by Joseph E.B. Lumbard, Pentagon Press, New Delhi, 2005 pp 237-283

3. Victor Segesvary, Form Illusion to Delusion : Globalization and the Contardictions of Late Modernity, International Scholars Publication, Bethesda, 1999, pp 14-15 with reference to Ejaz Akram,Ibid

4. Ibid, p. 16

5. Lamin Sanneh, Sacred and Secular in Islam : International Institute for the Study of Islam in the Muslim World, ISIM \# 10:02, p. 6 with reference Ejaz Akram, Ibid

6. www. Netureikarta. Org/

7. Mircea Eliade, The Sacred and the Profane : The Nature of Religion, Harcourt Brace, Orlando, 1987, pp. 10-11

8. Levine, Muslim Responses to Globalization, p. 1 with reference Ejaz Akram, Ibid

9. W.c. Smith, Modern Islam in India- A Social Analysis, Usha Publications, New Delhi, 1985, p. 7 , preface.

10. Ibid, p. 3

11. Ibid, p. 5

12. Ibid, pp. 49-110

13. Ibid, pp. 113-150 
14. Ibid, pp. 155-183

Web journal- Islam and Modern Age, August-September 2007, www.Isla.com 